\title{
Methylmercury and Total Mercury in Sediments Collected from the East China Sea
}

\author{
J.-B. Shi, L.-N. Liang, C.-G. Yuan, B. He, G.-B. Jiang
}

Key Laboratory of Environmental Chemistry and Ecotoxicology, Research Center for Eco-Environmental Sciences, Chinese Academy of Sciences, Post Office Box 2871, 100085 Beijing, Peoples Republic of China

Received: 12 May 2004/Accepted: 16 February 2005

The extensive application of mercury compounds in agriculture and industry has resulted in serious mercury contaminations in the past years. Now mercury has become one of the global pollutants because higher concentrations have been detected in the deep ocean, the atmosphere, Antarctica and the Arctic (Fergusson 1990). As the most toxic and the most familiar organomercury compound in the environment, methylmercury ( $\mathrm{MeHg}$ ) has often been given particular concern. In aquatic system, sediment is an important sink and source of mercury. Mercury can be bound to organic carbon-containing particles and accumulated in sediment and it can also be released annually from sediments to surrounding media on the other hand (Stein et al. 1996). In addition, sediment, in which inorganic mercury can be converted to organic mercury by biomethylation or abiotic methylation, has also been considered as the main $\mathrm{MeHg}$ production site. Therefore, investigation of concentrations and species of mercury in sediments helps us to understand its transformation and distribution in the environment.

The East China Sea is the end-point of two famous rivers in China, Changjiang River and Qiantang River (Fig. 1). Along the coast there are many developed cities including Shanghai and Ningbo and a number of factories have also been set up there. The inpouring of Changjiang River, Qiantang River and the wastewater produced by factories has caused serious pollution in the East China Sea. As a result, several serious harmful algal blooms occurred in this area during 1990s (Ye and Huang 2003). Quantities of fish and shellfish died, which resulted in very large economic losses. On the other hand, Zhoushan Archipelago, a large fishery near to Hangzhou Bay, is one of main sources of fishes provided to markets all over the China. These situations urge the investigation of the mercury pollution in this area because mercury is easily accumulated in fish and affect human health ultimately. However, mercury contamination in this place was few studied and is still not very clear. The aim of this work is to investigate the concentrations and species of $\mathrm{Hg}$ in sediments of the East China Sea. The vertical and planar distributions of $\mathrm{HgT}$ and $\mathrm{MeHg}$ were both studied. The effects of some factors on the methylation of inorganic mercury in the East China Sea sediments were also investigated.

\section{MATERIALS AND METHODS}

Twenty-four sediment samples from eight sites in the East China Sea were collected 


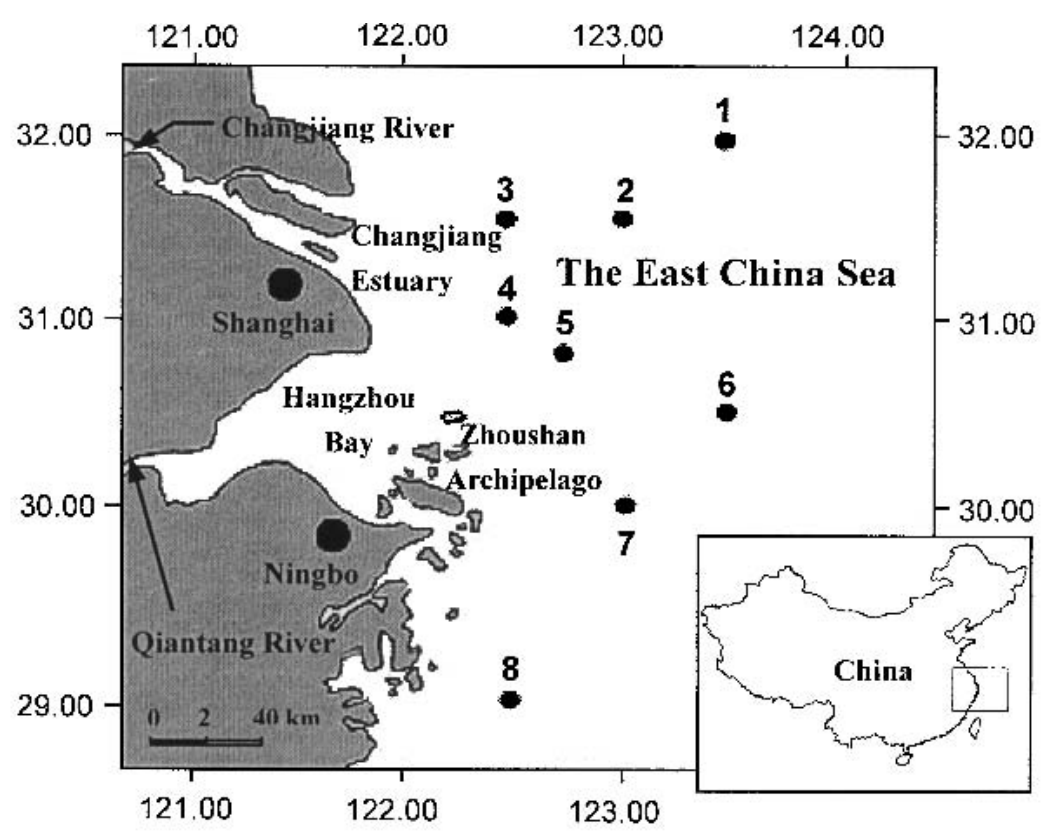

Figure 1. Map of study arca.

Table 1. The geographic positions and depths of water in the sampling sites.

\begin{tabular}{cccc}
\hline Sample site & Geographic position & Depth of water (m) \\
\hline 1 & $31^{\circ} 59.893^{\circ} \mathrm{N} ; 123^{\circ} 30.195^{\prime} \mathrm{E}$ & 39.8 \\
2 & $31^{\circ} 30.092^{\circ} \mathrm{N} ; 123^{\circ} 00.272^{\circ} \mathrm{E}$ & 36.5 \\
3 & $31^{\circ} 30.061^{\circ} \mathrm{N} ; 122^{\circ} 30.679^{\circ} \mathrm{E}$ & 28.5 \\
4 & $31^{\circ} 00.460^{\circ} \mathrm{N} ; 122^{\circ} 29.870^{\circ} \mathrm{E}$ & 16.5 \\
5 & $30^{\circ} 41.866^{\circ} \mathrm{N} ; 122^{\circ} 43.798^{\circ} \mathrm{E}$ & 65.8 \\
6 & $30^{\circ} 30.603^{\circ} \mathrm{N} ; 123^{\circ} 29.623^{\circ} \mathrm{E}$ & 58.3 \\
7 & $30^{\circ} 00.220^{\circ} \mathrm{N} ; 123^{\circ} 00.507^{\circ} \mathrm{E}$ & 51.0 \\
8 & $29^{\circ} 00.098^{\circ} \mathrm{N} ; 122^{\circ} 30.665^{\circ} \mathrm{E}$ & 50.1
\end{tabular}

in November 4-15, 2002 and the map of study area is shown in Fig. 1. The geographic positions and depths of water in the sampling sites are shown in table 1. The site 1 is located in far north of the Changjiang Estuary, where is hardly affected by the water of the Changjiang river. The result of this site can act as background in this work. Sites 2 and 3 stand the same longitude as the Changjiang Estuary and arc possibly polluted. In contrast to them, sites 4 and 5 have the most risk to be polluted because they are located in the junction of the Changjiang Estuary and Hangzhou Bay. Site 6 lies in line with sites 4 and 5, but far distance to them. Site 7 was selected in Zhoushan Archipelago. Sitc 8 is near to Ningbo city, and many other cities are also located there.

A rescarch vessel, Science No. I, was utilized during the voyage. The sediment cores were collected using a self-gravity sampling implement consisting of a $60 \mathrm{~cm}$ 
plastic sampling tube. Upon retrieving the core in deck, different depth of sediments were subsampled with a plastic spatula. Due to little sediments were collected from sites 1 and 2, only top sediments $(0-1 \mathrm{~cm})$ were sampled. All the sediments were placed into polytetrafluoroethylene (PTFE) bags, then frozen at $-20^{\circ} \mathrm{C}$ immediately after the collection. Before analyzing, the sediments were freezing dried, ground and passed through a 40 -mesh sieve, then thoroughly homogenized and kept in a silicagel desiccator.

For total mercury $(\mathrm{HgT})$ analysis, $0.25 \mathrm{~g}$ of sediments were weighed and added $5 \mathrm{~mL}$ of Milli-Q water and $5 \mathrm{~mL}$ of aqua regia in a $25 \mathrm{~mL}$ graduated tube. The mixture in the tube was then heated for $2 \mathrm{hrs}$ in a water bath at $95^{\circ} \mathrm{C}$ and shaken frequently. After cooling, the contents were diluted to $25 \mathrm{~mL}$ with Milli-Q water. When the solution was limpid, the HgT was then determined with a model AF-610A atomic fluorescence spectrometer (AFS, Beijing Raleigh Analytical Instrument Co., China). The method detection limit $(3 \sigma)$ obtained for sediments was approximately $0.5 \mathrm{ng} \mathrm{g}^{-1}$. In order to validate the method, the $\mathrm{HgT}$ in certified reference material (CRM) GBW07310 (sediment) was analyzed. The mean value and the deviation of five parallel determinations were shown in table 2 .

The determination of methylmercury (MeHg) in sediments was based on acid extraction and HPLC-CVAFS detection with the following modifications. Five grams of sediment were weighed into a $50 \mathrm{~mL}$ centrifuge tube and $25 \mathrm{~mL}$ of $6 \mathrm{~mol} \mathrm{~L}^{-1}$ $\mathrm{HCl}$ solution was added. The tube was shaken overnight, and then $15 \mathrm{~mL}$ of $\mathrm{CH}_{2} \mathrm{Cl}_{2}$ was added into the tube and shaking for another 2 hrs to extract organic mercury into the $\mathrm{CH}_{2} \mathrm{Cl}_{2}$ phase. After centrifuging at 2000rpm for $10 \mathrm{~min}$, the $\mathrm{CH}_{2} \mathrm{Cl}_{2}$ phase was transferred and concentrated on a rotary evaporator to about $1 \mathrm{~mL}$. Then the $\mathrm{CH}_{2} \mathrm{Cl}_{2}$ solution was transferred into a $10 \mathrm{~mL}$ glass tube, diluting to $4 \mathrm{~mL}$ with $\mathrm{CH}_{2} \mathrm{Cl}_{2}$ solution. At last, the solution was extracted with $1 \mathrm{~mL} 0.01 \mathrm{~mol} \mathrm{l}^{-1}$ of sodium thiosulfate. Shaking $45 \mathrm{~min}$ was needed to hasten the extraction speed. Setting for a few minutes for phase separation, the water phase was removed by micropipette and transferred into a clean $1 \mathrm{ml}$ screw cap glass vial. The laboratory-established HPLC-CVAFS hyphenation system, including a P680 HPLC pump (DIONEX, USA), a homemade microwave digestion device and a model AF-610A AFS (Beijing Raleigh Analytical Instrument Co., China), has been described previously (Liang et al. 2003). The method detection limit obtained for $\mathrm{MeHg}$ in sediments was approximately $0.2 \mathrm{ng} \mathrm{g}^{-1}$ as $\mathrm{Hg}$. The HPLC-CVAFS system was validated with CRM DORM-2 (Dogfish muscle) and the result was in good agreement with the certified values (table 2). Due to lack of sediment certified reference materials for $\mathrm{MeHg}$ in our laboratory, $10 \mu \mathrm{L}$ of $2 \mu \mathrm{g} \mathrm{mL} \mathrm{m}^{-1} \mathrm{MeHg}$ standard solutions were added into two sediments collected from site 5 (surface and $20 \mathrm{~cm}$ ) and the recoveries of $\mathrm{MeHg}$ were between $90 \%-112 \%$.

For $\mathrm{Fe}$ and $\mathrm{Mn}$ analysis, $0.1 \mathrm{~g}$ of sediment was directly weighed into a PTFE digestion container. $2 \mathrm{~mL}$ of $\mathrm{HNO}_{3}, 2 \mathrm{~mL}$ of $\mathrm{H}_{2} \mathrm{O}_{2}$ and $0.5 \mathrm{~mL}$ of $\mathrm{HF}$ were added in sequence. The container was sealed and placed in stainless steel bomb with a 
Table 2. Analytical results of total mercury, manganese, iron and methylmercury contents in certified reference materials ${ }^{*}$.

\begin{tabular}{lcccc}
\hline \multirow{2}{*}{ Element } & \multicolumn{2}{c}{ GBW07310 (sediment) } & \multicolumn{2}{c}{ DORM-2 (Dogfish muscle) } \\
\cline { 2 - 5 } & Certified & Determined & Certified & Determined \\
\hline $\mathrm{HgT}\left(\mathrm{ng} \mathrm{g}^{-1}\right)$ & $280 \pm 40$ & $275 \pm 11$ & & \\
$\mathrm{Mn}\left(\mu \mathrm{g} \mathrm{g}^{-1}\right)$ & $1013 \pm 44$ & $945 \pm 9$ & & \\
$\mathrm{Fe}(\%)$ & 0.19 & $0.19 \pm 0.01$ & & \\
$\mathrm{MeHg}\left(\mathrm{ng} \mathrm{g}^{-1}\right)$ & & & $4470 \pm 320$ & $4237 \pm 143$ \\
${ }^{{ }^{-1}}$ Mean $\pm \mathrm{s}, \mathrm{n}=5$ & & & &
\end{tabular}

screwclosure to avoid any acid leakage and placed in an oven. The oven was heated and the temperature was kept at $180^{\circ} \mathrm{C}$ for $8 \mathrm{hrs}$. After cooling to room temperature, the solution was completely transferred into a $100 \mathrm{~mL}$ volumetric flask and diluted with Milli-Q water. Then Fe and Mn in solutions were determined by Agilent $7500 \mathrm{i}$ inductively coupled plasma-mass spectrometry (ICP-MS, Agilent Technologies Co. Ltd. USA) at recommendatory conditions. For accuracy, the $\mathrm{Fe}$ and $\mathrm{Mn}$ concentrations in CRM GBW07310 (sediment) were determined and the results are also shown in table 2 .

\section{RESULTS AND DISCUSSION}

The concentrations of $\mathrm{HgT}, \mathrm{MeHg}$ and the ratios of $\mathrm{MeHg}$ to $\mathrm{HgT}$ are shown in table 3. HgT concentrations in sediments ranged from $<0.5$ to $79.8 \mathrm{ng} \mathrm{g}^{-1}$ (dry weight) and the average value was $37.0 \mathrm{ng} \mathrm{g}^{-1}$. The highest $\mathrm{MeHg}$ concentration was $5.5 \mathrm{ng} \mathrm{Hg} \mathrm{g}{ }^{-1}$ (dry weight) and the average value was $2.7 \mathrm{ng} \mathrm{Hg} \mathrm{g}^{-1}$. As shown in table 4, the concentrations of $\mathrm{HgT}$ are similar with those in South Florida Estuaries and Malaysian coast, and lower than those in other estuaries. On the other hand, the $\mathrm{MeHg}$ concentrations are similar with those in Scheldt Estuary and Seine Estuary (France), but higher than those in other locations. The background level of HgT in sea sediments was reported between 50ng g $\mathrm{g}^{-1}$ and $80 \mathrm{ng} \mathrm{g}^{-1}$ (Fujii 1976) and $\mathrm{MeHg}$ concentrations were typically lower than $10 \mathrm{ng} \mathrm{g}^{-1}$ for estuarine sediments (Mikac et al. 1999). Therefore, we concluded that the sediments from the East China Sea were not contaminated with mercury. However, higher percentages of $\mathrm{MeHg}$ (average: $8.8 \%$ ) were found in this work because the $\mathrm{MeHg}$ contents in sediments account for normally $1 \%$ to $1.5 \%$ of $\mathrm{HgT}$ except for some lakes and wetlands where the percentage of $\mathrm{MeHg}$ can reach $10 \%$ (Gilmour et al. 1992). The exactly reason for this high percentage was not clear because the methylation and demethylation of $\mathrm{Hg}$ in sediment could be affected by lots of factors including total $\mathrm{Hg}$ level, organic matter content, oxygen, temperature, $\mathrm{pH}$, salinity, chloride, sulphate and sulphide (Ullrich et al. 2001). The relationship between $\mathrm{HgT}$ and $\mathrm{MeHg}$ was also investigated. $\mathrm{HgT}$ was not correlated $(\mathrm{r}=0.41, \mathrm{n}=20$ ) with $\mathrm{MeHg}$, suggesting that factors other than HgT loading control the MeHg contents in sediments of the East China Sea. Therefore, the $\mathrm{HgT}$ concentration was not always a good predictor of $\mathrm{MeHg}$ level in aquatic system (Craig and Moreton 1983; Kannan et al. 1998a). 
Table 3. Concentrations of total and methyl mercury, total organic carbon, iron and manganese in sediments (dry weight).

\begin{tabular}{cccccccc}
\hline Site & Depth & $\begin{array}{c}\mathrm{HgT} \\
\left(\mathrm{ng} \mathrm{g}^{-1}\right)\end{array}$ & $\begin{array}{c}\mathrm{MeHg} \\
(\mathrm{ng} \mathrm{Hg} \\
\left.\mathrm{g}^{-1}\right)\end{array}$ & $\begin{array}{c}\mathrm{MeHg} \\
/ \mathrm{HgT} \\
(\%)\end{array}$ & $\begin{array}{c}\mathrm{TOC} \\
\left(\mathrm{mg} \mathrm{g}^{-1}\right)\end{array}$ & $\begin{array}{c}\mathrm{Fe} \\
\left(\mathrm{mg} \mathrm{g}^{-1}\right)\end{array}$ & $\begin{array}{c}\mathrm{Mn} \\
\left(\mathrm{mg} \mathrm{g}^{-1}\right)\end{array}$ \\
\hline 1 & $0-1 \mathrm{~cm}$ & 4.2 & $<0.2$ & & 3.03 & 2.11 & 0.37 \\
2 & $0-1 \mathrm{~cm}$ & $<0.5$ & $<0.2$ & & 1.42 & 1.75 & 0.57 \\
& $0-1 \mathrm{~cm}$ & 3.7 & $<0.2$ & & 3.76 & 1.98 & 0.50 \\
3 & $15 \mathrm{~cm}$ & $<0.5$ & $<0.2$ & & 3.17 & 2.00 & 0.38 \\
& $30 \mathrm{~cm}$ & 23.7 & 2.0 & 8.4 & 5.84 & 2.16 & 0.39 \\
& $0-1 \mathrm{~cm}$ & 62.3 & 5.5 & 8.8 & 6.98 & 3.03 & 0.68 \\
& $10 \mathrm{~cm}$ & 51.0 & 3.3 & 6.5 & 6.14 & 2.77 & 0.68 \\
4 & $20 \mathrm{~cm}$ & 42.9 & 3.1 & 7.2 & 6.50 & 2.59 & 0.59 \\
& $30 \mathrm{~cm}$ & 53.3 & 2.2 & 4.1 & 5.58 & 2.67 & 0.61 \\
& $40 \mathrm{~cm}$ & 50.0 & 3.0 & 6.0 & 5.52 & 2.52 & 0.53 \\
& $0-1 \mathrm{~cm}$ & 27.5 & 2.2 & 8.0 & 9.26 & 2.96 & 0.56 \\
5 & $10 \mathrm{~cm}$ & 44.4 & 1.9 & 4.3 & 9.29 & 2.55 & 0.52 \\
& $20 \mathrm{~cm}$ & 25.0 & 1.9 & 7.6 & 8.31 & 2.76 & 0.48 \\
& $30 \mathrm{~cm}$ & 66.7 & 2.2 & 3.3 & 8.44 & 2.75 & 0.49 \\
6 & $0-1 \mathrm{~cm}$ & 8.0 & 1.7 & 21.3 & 2.39 & 1.71 & 0.35 \\
& $15 \mathrm{~cm}$ & 14.0 & 1.3 & 9.3 & 2.96 & 1.56 & 0.31 \\
7 & $0-1 \mathrm{~cm}$ & 12.3 & 1.4 & 11.4 & 6.55 & 1.83 & 0.38 \\
& $15 \mathrm{~cm}$ & 6.1 & 1.6 & 26.2 & 6.34 & 2.09 & 0.38 \\
& $0-1 \mathrm{~cm}$ & 47.0 & 2.5 & 5.3 & 9.24 & 3.25 & 0.63 \\
& $10 \mathrm{~cm}$ & 79.8 & 1.8 & 2.3 & 8.60 & 2.94 & 0.53 \\
8 & $20 \mathrm{~cm}$ & 39.7 & 3.0 & 7.6 & 7.90 & 2.78 & 0.47 \\
& $30 \mathrm{~cm}$ & 58.9 & 2.2 & 3.7 & 6.77 & 2.85 & 0.44 \\
& $40 \mathrm{~cm}$ & 33.4 & 5.2 & 15.6 & 7.36 & 2.59 & 0.45 \\
& $50 \mathrm{~cm}$ & 59.8 & 5.1 & 8.5 & 6.75 & 2.85 & 0.48 \\
\hline \multirow{4}{*}{6} & & & & & & & \\
\hline
\end{tabular}

Table 4. Concentrations of total mercury and methylmercury in sediments from different estuaries and coasts.

\begin{tabular}{lccl}
\hline \multicolumn{1}{c}{ Location } & $\begin{array}{c}\text { Total mercury } \\
\left(\mathrm{ng} \mathrm{g}^{-1}\right)\end{array}$ & $\begin{array}{c}\text { Methylmercury } \\
\left(\mathrm{ng} \mathrm{g}^{-1}\right)\end{array}$ & Reference \\
\hline South Florida Estuaries & $20(1-219)$ & $\begin{array}{c}0.078 \\
(<0.001-0.49)\end{array}$ & Kannan et al. 1998a \\
Malaysian coast & $61(20-127)$ & $0.04(0.01-0.05)$ & Kannan et al. 1998b \\
Polish coast & $164(37-880)$ & $0.64(0.04-2.0)$ & Kannan et al. 1998b \\
San Francisco Bay & $200(20-700)$ & $0.4(0.1-1)$ & Conaway et al. 2003 \\
Anadyr Estuary, Russia & $339(77-2100)$ & $0.24(0.06-0.62)$ & Kannan et al. 1998b \\
Scheldt Estuary & $(144-1890)$ & $(0.8-6)$ & Baeyens et al. 1998 \\
Seine Estuary, France & 460 & $2.3(0.1-6)$ & Mikac et al. 1999 \\
\hline
\end{tabular}

Because the concentrations of $\mathrm{Hg}$ in estuaries are directly related to the sources of contamination, mercury behavior often differs from one estuary to another (Horvat 
et al. 1999). As mentioned above, two famous rivers, Changjiang River and Qiantang River, enter into the East China Sea. As the largest one in China and the third largest in the world, the Changjiang River carries a total of ca. $470 \times 10^{6}$ tones of fine sediments to the East China Sea annually. Guo et al. (2000) has reported that the geochemical characters of surface sediments in the East China Sea have a very close correspondence to those of Changjiang River sediments. Therefore, Changjiang River might be the main source of mercury to the East China Sea. The planar distribution of $\mathrm{HgT}$ and $\mathrm{MeHg}$ contents in surface sediments were depicted in Fig. 2. The $\mathrm{HgT}$ was not detectable in site 2 and the $\mathrm{MeHg}$ was not detectable in sites 1, 2 and 3 too. The possible reason might be that these three sites are located in the north of the Changjiang Estuary and far from it thus are hardly influenced by it. In contrast to this, site 4, being located in the junction of Changjiang Estuary and Hangzhou Bay, had the highest $\mathrm{HgT}$ and $\mathrm{MeHg}$. This was caused by the flow direction of water from Changjiang Estuary and Hangzhou Bay, which influenced the ultimate deposition of the pollutants. The $\mathrm{HgT}$ and $\mathrm{MeHg}$ contents in sediments of site 8 just took the second place because this site lies very close to the coast and many cities are located there. In addition, from $\mathrm{HgT}$ and $\mathrm{MeHg}$ contents in sites 4 to 7 , a distinct conclusion can be made that the pollution status alleviated with the distance to the Changjiang Estuary thus sediment of site 6 had lower mercury contents than others. Although little reported, from above results we can speculate that the drainage of water from Changjiang Estuary and the effluents from those seaside cities are the main sources of mercury in the East China Sea.

Sediments cores were also collected in six sites except sites 1 and 2. The deepest sediment was collected from site 8 at $50 \mathrm{~cm}$. Xia et al. (1999) reported the sedimentation rate in the East China Sea was $2.5-3.0 \mathrm{~cm} / \mathrm{a}$. This showed the samples collected were all sedimentated during the past 20 years. The concentrations HgT and $\mathrm{MeHg}$ in sediments from different depth are shown in table 3. There was no significant relationship between the concentrations of $\mathrm{HgT}$ and depth, indicating that the changes of $\mathrm{HgT}$ concentrations in past 20 years were little. For $\mathrm{MeHg}$, the concentrations in surface sediments were higher than those in deeper ones except site 7 and the highest $\mathrm{MeHg}$ concentration was found in surface sediment from site 4 $\left(5.5 \mathrm{ng} \mathrm{g}^{-1}\right)$. This is probably because temperatures and anoxic conditions are most conductive to methylation in the upper sediment zone and the methylation rates are greatest in the surface sediments (Stein et al. 1996). However, $\mathrm{MeHg}$ concentrations were unexpected increased in sediments from $30 \mathrm{~cm}$ and $40 \mathrm{~cm}$ from sites 4 and 8.

Organic carbon plays an important role in the bioavailability and methylation of inorganic mercury although its role has not been well understood. Ullrich et al. (2001) argued that, on the one hand, organic carbon could enhance methylation by stimulating the activity of heterotrophic microorganisms, or through direct abiotic methylation of $\mathrm{Hg}$ by humic or fulvic substances. On the other hand, $\mathrm{Hg}$ methylation may be inhibited at high DOC concentrations due to increased complexation of $\mathrm{Hg}$ with organic ligands, reducing $\mathrm{Hg}$ bioavailability to bacterias, particularly in the neutral $\mathrm{pH}$ range. Total organic carbon (TOC) concentrations in sediments were determined (table 3), which ranged from $1.42 \mathrm{mg} \mathrm{g}^{-1}$ to $9.29 \mathrm{mg} \mathrm{g}^{-1}$ and the average value was $6.17 \mathrm{mg} \mathrm{g}^{-1}$. The TOC contents showed a significant correlation $(\mathrm{r}=0.57$, 


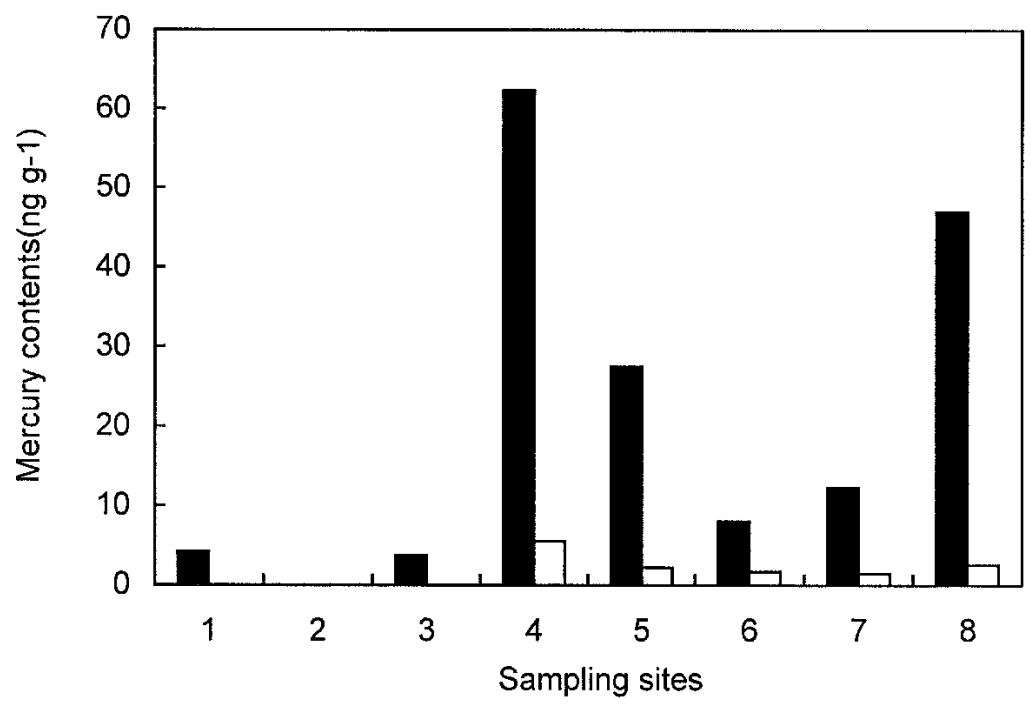

Figure 2. Distribution of $\mathrm{HgT}$ and $\mathrm{MeHg}$ in surface sediments.

(ם) Total mercury, ( $\square$ ) Methylmercury

$\mathrm{p}=0.99 ; \mathrm{n}=22)$ with $\mathrm{HgT}$ contents but not correlated $(\mathrm{r}=0.13 ; \mathrm{n}=20)$ with $\mathrm{MeHg}$ contents. This indicates that TOC contents partially control the level of $\mathrm{HgT}$ in sediments of the East China Sea but don't affect the distribution of $\mathrm{MeHg}$ contents.

The redox cycling of $\mathrm{Fe}$ and $\mathrm{Mn}$ oxides can also influence the MeHg in sediments by partly controlling the dissolved mercury concentrations in sediment porewaters (Gagnon et al. 1997). In the oxidized surface layers of marine sediments, $\mathrm{Hg}$ was found to be primarily associated with fresh particulate organic matter and $\mathrm{Fe}$ and/or Mn oxyhydroxides, which limited dissolved Hg concentrations. Gobeil and Cossa (1993) have also found that dissolved $\mathrm{Hg}$ and Fe concentrations increased below $2 \mathrm{~cm}$ from the sediment/water interface. The concentrations of $\mathrm{Fe}$ and $\mathrm{Mn}$ in sediments were investigated (shown in table 3). The mean content of $\mathrm{Fe}$ was 2.46 $\mathrm{mg} \mathrm{g}^{-1}$ (between 1.56 and $3.25 \mathrm{mg} \mathrm{g}^{-1}$ ) and the mean concentration of $\mathrm{Mn}$ was 0.49 $\mathrm{mg} \mathrm{g}^{-1}$ (from 0.31 to $0.68 \mathrm{mg} \mathrm{g}^{-1}$ ). The study of correlations indicated that $\mathrm{Fe}$ concentrations were significant correlated $(r=0.78, p=0.99 ; n=22)$ with $\operatorname{Hg} \Gamma$ contents and weak correlated $(r=0.47, p=0.95 ; n=20)$ with $\mathrm{MeHg}$ contents. Similarly, the Mn concentrations in sediments were also correlated $(r=0.63, p=0.99$; $\mathrm{n}=22)$ with $\mathrm{HgT}$ contents and weak correlated $(\mathrm{r}=0.45, \mathrm{p}=0.95 ; \mathrm{n}=20)$ with $\mathrm{MeHg}$ contents. The above results just illustrated that $\mathrm{Fe}$ and $\mathrm{Mn}$ played equal role in the methylation of mercury in the sediments. And this might be explained that $\mathrm{Fe}$ and $\mathrm{Mn}$ usually formed $\mathrm{Fe} / \mathrm{Mn}$ oxide and affected the available $\mathrm{Hg}$ and $\mathrm{Eh}$ in the sediment thereby influenced the methylation of mercury.

Acknowledgments. This work was jointly supported by the National Natural Science Foundation of China (20137010, 20205008) and the Chinese Academy of Science (KZCX2-414). 


\section{REFERENCES}

Baeyens W, Meuleman C, Muhaya B, Leermakers M (1998) Behaviour and speciation of mercury in the Scheldt estuary. Hydrobiologia 366: 63-79

Conaway CH, Squire S, Mason RP, Flegal AR (2003) Mercury speciation in the San Francisco Bay estuary. Mar Chem 80: 199-225

Craig PJ, Moreton PA (1983) Total mercury, methyl mercury and sulphide in River Carron sediments. Mar Pollut Bull 14: 408-411

Fergusson JE (1990) The Heavy Elements: Chemistry, Environmental Impact and Health Effects. Pergamon Press, Oxford

Fujii M (1976) Mercury distribution in lithosphere and atmosphere, in Mercury. Kitamura S, Kondo M, Takizawa Y, Fujii M, Fujiki M Eds, Kodansha Scientific, Tokyo

Gagnon C, Pelletier E, Mucci A (1997) Behaviour of anthropogenic mercury in coastal marine sediments. Mar Chem 59: 159-176

Gilmour CC, Henry EA, Mitchell R (1992) Sulfate stimulation of mercury methylation in freshwater sediments. Environ Sci Technol 26: 2281-2287

Gobeil C, Cossa D (1993) Mercury in sediments and sediments pore water in the Laurentian Trough. Canadian J Fish Aquat Sci 50: 1794-1800

Guo ZG, Yang ZS, Qu YH, Fan DJ (2000) Study on comparison sedimentary geochemistry of mud area in East China Sea continental shelf. Chinese J Acta Sedimentol Sinica 18: 284-289

Horvat M, Covelli S, Faganeli J, Logar M, Mandić V, Rajar R, Širca A, Žagar D (1999) Mercury in contaminated coastal environments; a case study: the Gulf of Trieste. Sci Total Environ 237/238: 43-56

Kannan K, Smith Jr RG, Lee RF, Windom HL, Heitmuller PT, Macauley JM, Summers JK (1998a) Distribution of total mercury and methyl mercury in water, sediment and fish from South Florida Estuaries. Arch Environ Contam Toxicol 34: 109-118

Kannan K, Falandysz J (1998b) Speciation and concentrations of mercury in certain coastal marine sediments. Water Air Soil Pollut 103: 129-136

Liang LN, Jiang GB, Liu JF, Hu JT (2003) Speciation analysis of mercury in seafood by using high-performance liquid chromatography on-line coupled with cold-vapor atomic fluorescence spectrometry via post column microwave digestion. Anal Chim Acta 477: 131-137

Mikac N, Niessen S, Ouddane B, Wartel M (1999) Speciation of mercury in sediments of the Seine Estuary (France). Appl Organometal Chem 13: 715-725

Stein ED, Cohen Y, Winer AM (1996) Environmental distribution and transformation of mercury compounds. Crit Rev Environ Sci Technol 26: 1-43

Ullrich SM, Tanton TW, Abdrashltova SA (2001) Mercury in the aquatic environment: a review of factors affecting methylation. Crit Rev Environ Sci Technol 31: 241-293

Xia XM, Xie QC, Li Y, Li BG, Feng YJ (1999) ${ }^{137} \mathrm{Cs}$ and ${ }^{210} \mathrm{~Pb}$ profiles of the seabed cores along the East China Sea coast and their implications to sedimentary environment. Chinese J DONGHAI Mar Sci 17: 20-27

Ye SF, Huang XQ (2003) HABs in East China Sea: surveillance and monitoring. Chinese J Mar Environ Sci 22: 10-14 